\title{
Weil's Disease (Fulminating Leptospirosis) Complicating as Acute Respiratory Distress Syndrome
}

\author{
Sahil N. Fulara, Nasir Y. Fulara \\ Department of Medicine, Jaslok Hospital and Medical Research Center, Mumbai, India \\ Email: drsahil.fulara@gmail.com
}

How to cite this paper: Fulara, S.N. and Fulara, N.Y. (2016) Weil's Disease (Fulminating Leptospirosis) Complicating as Acute Respiratory Distress Syndrome. Open Journal of Clinical Diagnostics, 6, 19-24. http://dx.doi.org/10.4236/ojcd.2016.63004

Received: August 1, 2016

Accepted: August 23, 2016

Published: August 26, 2016

Copyright $\odot 2016$ by authors and Scientific Research Publishing Inc. This work is licensed under the Creative Commons Attribution International License (CC BY 4.0).

http://creativecommons.org/licenses/by/4.0/ (c) (i) Open Access

\begin{abstract}
Leptospiroisis presents with a wide range of clinical symptoms, ranging from mild disease symptoms to life threatening complications. The clinical features and routine laboratory findings are not specific, and therefore a high index of suspicion must be maintained for the diagnosis. We documented a case of a patient, who presented with high grade fever, diarrhea, vomiting, had icterus on examination. Initial laboratory investigations revealed low platelet count, along with raised liver enzymes. IgM leptospirosis came positive and patients received broad spectrum antimicrobials and supportive fluid therapy. During admission, patient developed sudden onset breathlessness, which was diagnosed as acute respiratory distress syndrome after doing immediate arterial blood gases. The patient received noninvasive ventilation with positive airway pressure, from which the patient eventually recovered. Most of the cases of leptospirosis are uneventful with complete recovery. However, a minority of these cases may end with life threatening complications. A vaccine for human use is not available in most countries. Therefore, the prevention involves reducing exposure, either by avoiding situations that pose a risk of transmission or using protective clothing.
\end{abstract}

\section{Keywords}

Acute Respiratory Distress Syndrome, Leptospirosis, Noninvasive Ventilation, Zoonoses

\section{Introduction}

A wide spectrum of clinical presentation is exhibited by leptospirosis. Leptospirosis is a zoonosis with protean clinical manifestations caused by pathogenic spirochetes of the 
genus Leptospira. The organism infects a variety of wild and domestic mammals, especially rodents, cattle, swine, dogs, horses, sheep, and goats. Humans most often become infected after exposure to environmental sources, such as animal urine, contaminated water or soil, or infected animal tissue through cuts or abraded skin, mucous membranes, or conjunctiva. Most cases are mild and self-limited or subclinical, while some are severe and potentially fatal. Severe pulmonary disease, characterized by pulmonary hemorrhage, is a serious complication of leptospirosis; it may be underdiagnosed in highly endemic regions [1]. We describe a case of leptospirosis which later has proved to be acute respiratory distress syndrome.

\section{Case Report}

A 50-year-old driver presented to the casualty with complaints of fever with chills and decreased urine output since past two days. He also had two episodes of diarrhea and vomitting. The fever was high grade, intermittent, associated with chills and rigor. Antipyretics would control the fever but only temporarily. There were no complaints of burning micturation, cough, cold, swelling of feet or blood in urine. Patient's past medical history was insignificant for any major illness or hospitalization. On examination, vitals were within normal range, there was no evidence of pallor, cyanosis or clubbing. However, icterus was present. Bilateral crepts were heard and spleen was palpable, rest of the physical examination revealed no abnormalities. We ordered complete blood count, liver and renal function tests, serum electrolytes, IgM leptospirosis, malarial parasite, dengue antigen, widal test and routine urine examination. Initial set of investigations revealed high cell count, 30,000 platelets and 5.5 creatinine (Table 1). We started treating the patient with injection artesunate $120 \mathrm{mg}$, injection clindamycin 600 mg along with intravenous fluids and platelet tranfusion.

The next day patient developed sudden onset of breathlessness, for which the patient was shifted to intensive care unit. Immediate arterial blood gases pointed towards acute respiratory distress syndrome. Chest X-ray showed bilateral pulmonary hemorrhage (Figure 1). In the meanwhile, IgM leptospirosis came positive. We put the patient on noninvasive ventilation with positive airway pressure. Injection ceftriaxone was added to the treatment. The patient recovered on the 5th day and was stepped down to general ward. Later the patient was continued on the treatment for another 7 days and on full recovery the patient was discharged home. Follow-up visits and investigations were scheduled with the patient.

\section{Discussion}

Leptospirosis is a widespread and prevalent zoonotic disease. It occurs in both temperate and tropical regions of the world. Human infection usually results from exposure to environmental sources, such as animal urine, contaminated water or soil, or infected animal tissue. Portals of entry include cuts or abraded skin, mucous membranes, or conjunctivae. The clinical course of leptospirosis is variable. The illness generally presents with onset of fever, rigors, myalgias, and headache in 75 to 100 percent of 
Table 1. Investigations performed during admission of the patient.

\begin{tabular}{|c|c|c|c|c|c|}
\hline Investigation & Day 0 & Day 1 & Day 2 & Day 3 & Day 5 \\
\hline $\begin{array}{l}\text { Hemoglobin } \\
(\mathrm{gm} / \mathrm{dL})\end{array}$ & 12.5 & 11.7 & 11.4 & 11.7 & 12 \\
\hline \multicolumn{6}{|l|}{ Total Leucocyte } \\
\hline $\begin{array}{c}\text { Count } \\
\text { (cells/cu mL) }\end{array}$ & 10,430 & 12,350 & 9350 & 7600 & 5400 \\
\hline $\begin{array}{l}\text { Platelet count } \\
\quad(\text { cells } / \mu \mathrm{L})\end{array}$ & 30,000 & 54,000 & 103,000 & 172,000 & 268,000 \\
\hline $\begin{array}{c}\text { Blood Urea } \\
\text { Nitrogen }(\mathrm{mg} / \mathrm{dL})\end{array}$ & 46 & - & - & - & - \\
\hline $\begin{array}{l}\text { Serum Creatinine } \\
\qquad(\mathrm{mg} / \mathrm{dL})\end{array}$ & 5.5 & 4.9 & 3.0 & 1.8 & 0.8 \\
\hline $\begin{array}{l}\text { Serum Bilirubin } \\
(\mathrm{mg} / \mathrm{dL})\end{array}$ & 3.6 & 3.2 & 3.6 & 1.2 & 1 \\
\hline \multicolumn{6}{|l|}{ Aspartate } \\
\hline $\begin{array}{c}\text { transaminase } \\
(\mathrm{U} / \mathrm{L})\end{array}$ & 59 & 60 & 45 & 30 & 30 \\
\hline $\begin{array}{c}\text { Alanine } \\
\text { transaminase }(\mathrm{U} / \mathrm{L})\end{array}$ & 27 & 23 & 24 & 23 & 20 \\
\hline $\begin{array}{l}\text { Serum Calcium } \\
(\mathrm{mg} / \mathrm{dL})\end{array}$ & 8.8 & - & - & - & - \\
\hline Vit. D (ng/mL) & 40 & - & - & - & - \\
\hline Sodium $(\mathrm{mEq} / \mathrm{L})$ & 131 & - & 136 & & 142 \\
\hline $\begin{array}{l}\text { Potassium } \\
(\mathrm{mEq} / \mathrm{L})\end{array}$ & 3.4 & - & 3.8 & & 4.1 \\
\hline Chloride $(\mathrm{mEq} / \mathrm{L})$ & 102 & - & 105 & & 108 \\
\hline $\begin{array}{l}\text { Random Blood } \\
\text { Sugar (mg/dL) }\end{array}$ & 84 & - & - & - & - \\
\hline \multirow{4}{*}{$\begin{array}{l}\text { Arterial Blood } \\
\text { Gases }\end{array}$} & pH: 7.26 & & pH: 7.4 & & pH: 7.42 \\
\hline & $\mathrm{pO}^{2}: 55$ & & $\mathrm{pO}^{2}: 85$ & & $\mathrm{pO}^{2}: 98$ \\
\hline & $\mathrm{pCO}^{2}: 235$ & - & $\mathrm{pCO}^{2}: 40$ & - & $\mathrm{pCO}^{2}: 42$ \\
\hline & $\mathrm{HCO}_{3}^{-}: 14$ & & $\mathrm{HCO}_{3}^{-}: 18$ & & $\mathrm{HCO}_{3}^{-}: 21$ \\
\hline
\end{tabular}

patients, following an incubation period of 2 to 26 days. The anicteric illness is typically biphasic, with an acute leptospiremic phase followed by an immune-mediated leptospiruric phase. Nonproductive cough occurs in 25 to 35 percent of cases; nausea, vomiting, and diarrhea occur in approximately 50 percent of cases. Muscle tenderness, splenomegaly, lymphadenopathy, pharyngitis, hepatomegaly, muscle rigidity, abnormal respiratory auscultation, or skin rash occur in 7 to 40 percent of patients [2]. Leptospirosis has been described as a biphasic illness (with an acute bacteremic phase followed by an "immune" phase); clinically, the two phases usually merge, particularly in severe disease. Aseptic meningitis is observed in 50 to 85 percent of patients if cerebrospinal fluid is examined after seven days of illness. In general, this finding has been attributed to a host immune response to the organism rather than to direct infection [3].

Severe pulmonary disease, characterized by pulmonary hemorrhage, is a serious complication of leptospirosis; it may be underdiagnosed in highly endemic regions. Among 321 patients with serologic and clinical evidence of leptospirosis in Peru, 3.7\% had severe pulmonary manifestations; of these, $71 \%$ died (causes of death included 


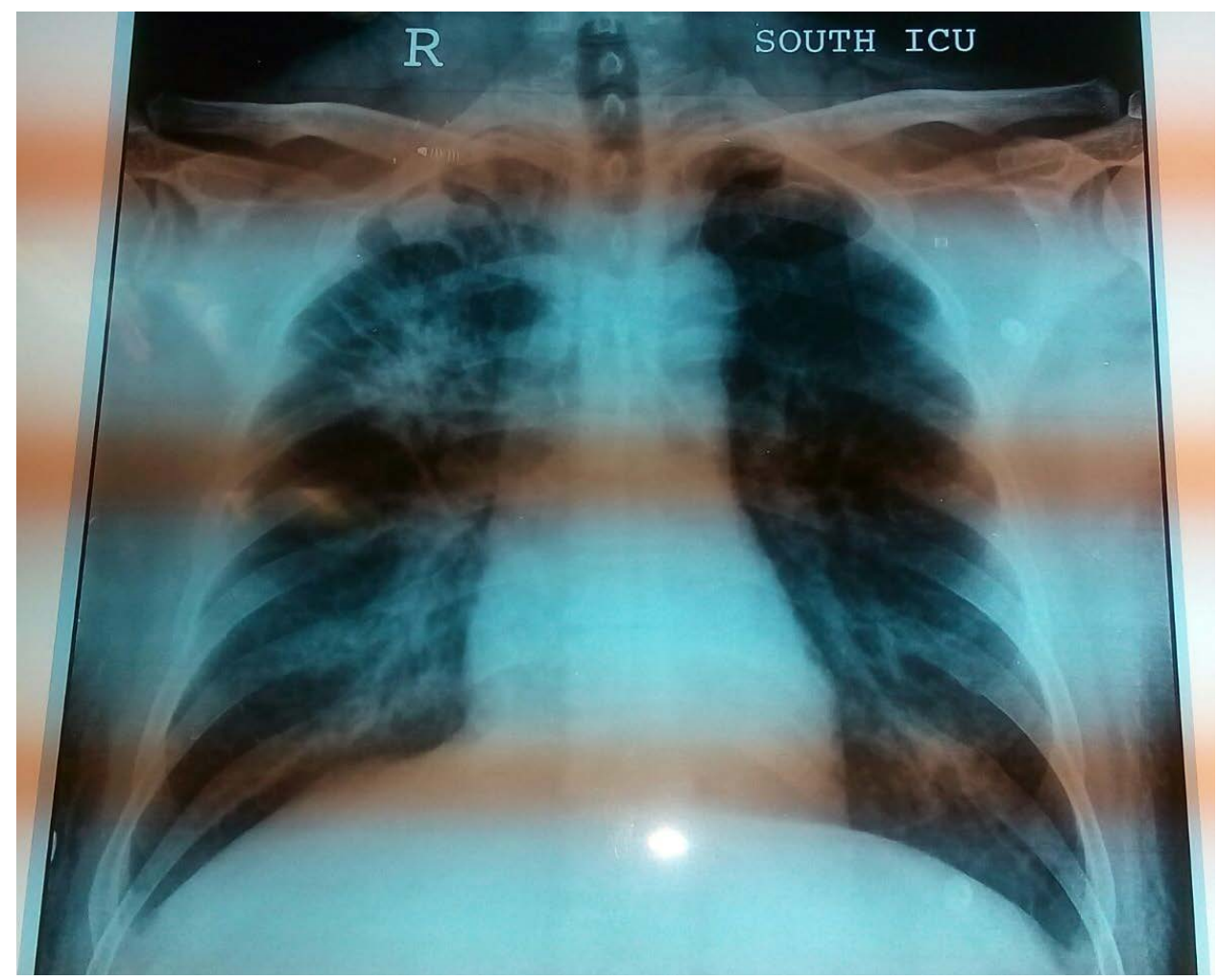

Figure 1. Chest X-ray showing bilateral infiltrates representing pulmonary hemorrhages.

pulmonary hemorrhage, ARDS, and multiorgan failure) [4]. In one retrospective review of 282 cases of leptospirosis during an outbreak in India, significant predictors of death in logistic regression analysis included pulmonary involvement and central nervous system disease [5]. The potential severity of leptospirosis was illustrated in a retrospective study of 60 patients with leptospirosis requiring intensive care unit (ICU) admission in India [6]. Multiorgan failure developed in 46 patients (77\%); the mortality for patients with leptospirosis requiring ICU admission was 52\%. Pulmonary hemorrhage is the severe pulmonary forms of leptospirosis and is usually massive, leading to respiratory insufficiency and death by asphyxiation [7]. Hemoptysis which is a manifestation of pulmonary hemorrhage, has been reported in about $17 \%$ - $50 \%$ of patients [8].

Routine laboratory tests may be nonspecific. High white blood cell count, thrombocytopenia, hyponatremia are some of the investigative findings found in leptospirosis. Approximately $40 \%$ of patients have minimal to moderate elevations of hepatic transaminases. Chest radiography may demonstrate small nodular densities, which can progress to confluent consolidation or a ground glass appearance. Pathologically, these infiltrates may represent alveolar hemorrhage, ARDS, or pulmonary edema, as were in the case of our patient. There is a lack of reference standard for diagnosis of leptospirosis; the microscopic agglutination test (MAT) and culture are both imperfect, either alone or in combination. However, serological tests like the microscopic agglutination test, macroscopic agglutination test, indirect hemagglutination, and enzyme-linked immunosorbent assay are used most frequently for diagnosis of leptospirosis. Molecu- 
lar techniques such as real-time polymerase chain reaction and loop-mediated isothermal amplification have been developed for diagnosis of leptospirosis. These are not widely available but are promising for rapid, accurate diagnosis.

Antimicrobial therapy is the mainstay of the treatment. In the setting of severe illness, supportive care with fluid replacement therapy, ventilatory support, and blood products may also be required. Use of intravenous steroid therapy has been proposed for severe leptospirosis, particularly in the setting of pulmonary involvement; however, there is insufficient evidence for routine use of corticosteroids. The most important control measures for preventing human leptospirosis include avoiding potential sources of infection such as stagnant water and animal farm water runoff, rodent control, and protection of food from animal contamination.

\section{Conclusion}

A high degree of suspicion is required to make the diagnosis based on epidemiologic exposure and clinical manifestations, since clinical and laboratory findings are nonspecific. Most cases of leptospirosis are mild to moderate. However, the course may be complicated by renal failure, uveitis, hemorrhage, acute respiratory distress syndrome with pulmonary hemorrhage, myocarditis, and rhabdomyolysis. Symptomatic patients presenting for medical attention should receive antimicrobial therapy to shorten the duration of illness and reduce shedding of organisms in the urine. Prevention measures include avoiding potential sources of infection, administration of prophylaxis for individuals at high risk of exposure.

\section{References}

[1] Assimakopoulos, S.F., Fligou, F., Marangos, M., Zotou, A., Psilopanagioti, A. and Filos, K.S. (2012) Anicteric Leptospirosis-Associated Severe Pulmonary Hemorrhagic Syndrome: A Case Series Study. The American Journal of the Medical Sciences, 344, 326-329. http://dx.doi.org/10.1097/MAJ.0b013e3182563927

[2] Berman, S.J., Tsai, C.C., Holmes, K., Fresh, J.W. and Watten, R.H. (1973) Sporadic Anicteric Leptospirosis in South Vietnam: A Study in 150 Patients. Annals of Internal Medicine, 79, 167-173. http://dx.doi.org/10.7326/0003-4819-79-2-167

[3] Romero, E.C., Blanco, R.M. and Yasuda, P.H. (2010) Aseptic Meningitis Caused by Leptospira spp Diagnosed by Polymerase Chain Reaction. Memórias do Instituto Oswaldo Cruz, 105, 988-992. http://dx.doi.org/10.1590/S0074-02762010000800007

[4] Segura, E.R., Ganoza, C.A., Campos, K., Ricaldi, J.N., Torres, S., Silva, H. and Gotuzzo, E. (2005) Clinical Spectrum of Pulmonary Involvement in Leptospirosis in a Region of Endemicity, with Quantification of Leptospiral Burden. Clinical Infectious Diseases, 40, 343351. http://dx.doi.org/10.1086/427110

[5] Pappachan, M.J., Mathew, S., Aravindan, K.P., Khader, A., Bharghavan, P.V., Kareem, M.M., Tuteja, U., Shukla, J. and Batra, H.V. (2004) Risk Factors for Mortality in Patients with Leptospirosis during an Epidemic in Northern Kerala. The National Medical Journal of India, 17, 240-242.

[6] Chawla, V., Trivedi, T.H. and Yeolekar, M.E. (2004) Epidemic of Leptospirosis: An ICU Experience. JAPI, 52, 619-622. 
[7] Im, J.G., Yeon, K.M., Han, M.C., Kim, C.W., Webb, W.R., Lee, J.S. and Chi, J.G. (1989) Leptospirosis of the Lung: Radiographic Findings in 58 Patients. American Journal of Roentgenology, 152, 955-959. http://dx.doi.org/10.2214/ajr.152.5.955

[8] Tanomkiat, W. and Poonsawat, P. (2005) Pulmonary Radiographic Findings in 118 Leptospirosis Patients. Southeast Asian Journal of Tropical Medicine and Public Health, 36, 1247.

Submit or recommend next manuscript to SCIRP and we will provide best service for you:

Accepting pre-submission inquiries through Email, Facebook, LinkedIn, Twitter, etc. A wide selection of journals (inclusive of 9 subjects, more than 200 journals)

Providing 24-hour high-quality service

User-friendly online submission system

Fair and swift peer-review system

Efficient typesetting and proofreading procedure

Display of the result of downloads and visits, as well as the number of cited articles

Maximum dissemination of your research work

Submit your manuscript at: http://papersubmission.scirp.org/ 